\title{
Professional Pathways of Educators of Educators. An Argentine-French study on identity, recognition and professionalization with an impact on employability.
}

\author{
DOI: $10.46932 / \mathrm{sfjdv2n2-032}$
}

Received in: january 1st, 2020

Accepted in: March 30th, 2020

\author{
Miriam Aparicio \\ CONICET (National Council for Scientific and Technical Research, Parque General San Martin, \\ Mendoza, Argentina) - Argentina (5500). Lead Researcher. \\ National University of Cuyo. \\ E-mail: miriamapar@yahoo.com
}

\author{
Alyson Nuñez \\ National University of Cuyo. \\ E-mail: alysonnunez@gmail.com
}

\begin{abstract}
Researchers around the world analyze the pathways of university educators and educators from Institutes of Teacher Formation, pathways which are conditioned by history and marked by the influence of context and the abrupt changes which have taken place recently. All of this together affects both teacher identity and employability. Our sample was made up of teachers from different levels, institutions, environments, provinces and from three different countries. In this work, we will compare findings from Institutes of Teacher Formation (IFD) in Argentina (Cuyo region) with those of institutes in France (IUFM from East Paris-Créteuil, France). This will allow us to capture contextual differences as they affect the level of objective achievement and satisfaction. The model includes base, sociocultural, psychosocial, organizational and structural factors. Our methodology was quanti-qualitative (lexicometric analysis and interviews). This allowed us to understand the central issue that each study program itself has and how it relates to the working world, as well as the distances between the prescribed world and the real world of these actors. We also applied a semi-structured survey with open-ended answers, which permitted us to utilize the technique of hierarchical evocation. The results show shared representations of teachers at the tertiary level in Argentina and France, illustrating strengths and weaknesses particularly regarding weakening recognition and global devaluation of teachers. The results will be presented to decision makers in education with aims to implement programs of Professionalization which could overcome the aspects that today fracture identities and create upset among teachers, impacting their employability.
\end{abstract}

Keywords: Identity, Pathways of university students, Professionalization, Recognition, Employability

\section{INTRODUCTION}

As regards the education of educators, Argentina has gone through deep transformations over the course of the last years which offer positive aspects and gray areas. In this article, we will focus, on the one hand, on the most important theoretical aspects at the macro level (social, historical, political) and at the meso-institutional level (educational system), which converge in a weakened identity in the teacher education system and in the teacher him or herself. On the other hand, we will give attention to empirical analysis, addressing the results of this research and of other prior research carried out within the 
framework of CONICET (1980-2020). All of this research is found on a line of continuity ${ }^{1}$. Before doing so, we will discuss the Methodology employed, both in France and in Argentina.

With regards to this, we point out that in Part I - Theoretical Framework - we will make reference to precedents which, for both countries, constitute the basis of a weakened "identity" among teachers. In terms of Part II - Empirical Analysis and Methodology - though we will present the results of the Argentine IFD and the French IUFM included in the study, in order to be brief we will only interpret the Argentine case as each country has singularities in its history, despite the fact that Argentina has always taken as a basis for its teacher formation programs, especially recently, the reforms carried out in France.

In research carried out in Argentina, Aparicio has analyzed factors constituting the base of achievement at the academic and socio-professional level for different populations of the education system (graduates, individuals who abandon their studies or change programs, individuals who extend their studies, students, educators, directors, state employees, administrative and technical personnel, PhDs, researchers, university professors, etc.). Two main aspects characterize these studies within a wider program of evaluation of the quality of educational institutions (Aparicio, 2005-2009).

Firstly, priority has been given to the analysis of psychosocial, pedagogical-institutional and structural processes when faced with numerous studies of "figures", seeking to reveal the "meaning" and the "deeper reasons" behind the situations and practices observed. With regard to what concerns us here, focus has been placed on understanding the conditions that impact teachers currently, favoring or hindering the daily practice of their "métier" and, particularly, creating more fragile identities. Within these psychosocial processes which weave between the individual and his or her respective contexts, influencing pathways and, indirectly, employability, we choose to highlight recognition.

Secondly, we have adopted a macro-meso-micro-macro strategy of analysis, an analysis still not widespread in our field and not supported in discourse but rather in research carried out in the field, in order to attempt to arrive at a more integral approximation that joins the macro-social, meso-institutional and individual actor levels, all in interaction. We seek a systemic approximation which reveals the "comings and goings" between the sociocultural, institutional, structural and individual systems, interactions that favor or limit actions and opportunities for development. As such, we provide a sui generis reading of the situation regarding the education of educators and professionalization, utilizing a paradigm of complexity and, more precisely, a sui generis systemic theory entitled The Three Dimensional Spiral of Sense (Aparicio, 2015 a and b, published in India), though here we will not go into detail on this as it exceeds our objective (Aparicio, 2006 a and b; 2009 a and b; 2012).

\footnotetext{
${ }^{1}$ The latest project is titled: Trayectorias laborales, Satisfacción, Profesionalización e Identidad. Un estudio en la UNCuyo en distintos contextos organizacionales (científicos, docentes y administrativos)”. PICTO. Programas de Investigación Científica y Tecnológica Orientados, Agencia Nacional de Ciencia, Tecnología e Innovación. 2016-2020. Argentina.
} 


\section{PART I. THEORETICAL FRAMEWORK}

We outline two aspects of the issue which are at the origin of what we call a "weakened identity", an identity which runs throughout the education of educators at different levels.

The following plan will be followed:

I) Brief history of the Education of Educators and, particularly, of the INFD (National Institute of Teacher Formation) created in 2007 , as well as the effects of its creation on the level of professional and institutional identity.

a) We highlight only the most outstanding events throughout history and their effects, both visible and invisible, until the creation of the National Institute of Teacher Formation (INFD), with the positive and negative changes that this implied in the functions.

b) Among these functions, we will focus more on one aspect: the recognition of teachers and the devaluation of their function, which has impacts on the fragility of their identity and their employability.

c) Finally, we highlight the base of the social representations (shared by teachers) linked to one of the many aspects studied in global research: weakness of social recognition.

II) Status of the education of educators in Argentina as a semi-profession and its relationship with weakened identity.

Today, many other issues are added to this. On the one hand, that of the increasing demands of the teaching context, particularly in less developed countries where teachers are not only teachers but also serve as a kind of social worker; on the other, that of the new characteristics of populations coming from disadvantaged areas and, especially, "novice" teachers. The results of international research and our own indicate the perception of marked distance between the "ideal teacher" and the "real teacher", between the world expected when choosing a program of study and the world which teachers truly face.

These issues reveal the renewed need for professionalization within the framework of the education of educators. 


\section{THE EDUCATION OF EDUCATORS: HISTORY AND ITS EFFECTS}

\subsection{FRAGMENTATION AND ITS ROOTS}

We will now address the main issues which currently characterize the institutional situation of the Argentine education system.

The education of educators is a continuous and long lasting process which does not end with the initial courses. The teaching profession is constantly called upon because of changes to different spheres of society, culture, politics, technology and scientific knowledge. This macro-meso relationship has already been outlined (though in other terms) in the national document where professionalization of teaching is a fundamental strategy for renewing "métier" and for responding to society's current needs, evidencing the complexity of the teaching role and of the cultural mediation that they ensure in its different dimensions (political, sociocultural and pedagogical) (cf. Lineamientos Nacionales para la Formación Docente Continua y el Desarrollo Profesional, item 11).

In order to identify the institutional issues at the meso level and those impacting actors at the micro level, we will mention some historical instances and, particularly, the latest: the creation in 2007 of the INFD as part of the National Strategic Plan for the Education of Educators (2004-2007). It is important to note that in our analysis we took into account contributions made by international commissions gathered as part of bilateral agreements, particularly between Argentina and France (2005-2007). These commissions have delved into the organization of our education system as it relates to international systems and have observed its most notable failings (Gelin, Rayou \& Ria, 2007).

Doing a quick review, in the past and until 1988, teacher education in Argentina took place in Normal Schools, that is, as part of the secondary cycle of education. In that year, the National Office of Higher Education was created, with teacher education passing to this level though without registering great changes.

An important event in this history was the abrupt transfer of the educational administration of teacher education to the jurisdiction of the provinces in 1994, an event which would have both visible and invisible consequences.

To all of this was added the processes of accreditation. The IFD were required to undergo a series of evaluations to certify certain institutional and curricular conditions judged appropriate for the functioning of education (among them, continuing education and research) ${ }^{2}$.

In addition to the visible effects of these policies (transference, curricular changes, institutional accreditation), another less visible also occurred, fragmentation. In effect, the national policies adopted

\footnotetext{
2 These aspects will be addressed in depth in a future article.
} 
did not show certain homogeneity, causing a lack of organic identity and weak integration in terms of the system.

The passing of National Education Law 26.206 marked a new phase in the education of educators as the National Institute of Teacher Formation (INFD) was created. Its objective was: a) to overcome a state of disorganization through the articulation of Institutes and Universities; b) to reinforce cohesion, unity, identity and organization of the system of teacher education in the country; and c) to guide policies for improvement within the framework of the long-term Strategic Plan. Nevertheless, the desire to reach a certain unity and homogeneity led to the neglect of the needs of particular institutions, that is, "situated" needs.

Moreover, among the changes, it is important to note that within the INFD the Department of Institutional Development is created which seeks an integrated federal system (more than 700 national institutes at that time). A Department of Education and Research is also created. Its function is to carry out research and promote best pedagogical practice, taking into account that despite ongoing efforts since 1993, research is still weak in this sector (cf. Hacia un Acuerdo sobre la Institucionalidad del Sistema de Formación Docente en la Argentina, item 14, p. 16-17).

We will not focus on the internal organization and strategies of the INFD.

\section{TOWARDS A BALANCE}

\subsection{GLOBAL LEVEL}

The central issue in terms of teacher education can be summed up in one word: fragmentation. In fact, the fragmentation of the system in private institutes and the autonomy that they enjoyed with fragile and bureaucratic systems and poor resources created segmentation and isolation.

This seems to lead to an issue of weakened institutional identity which requires reinforcement of management, cohesion and the organization of the system of higher education.

Putting this into perspective, we must review the unequal results achieved and the quasi absence of research. This weakness, which also emerges in this context in other countries, has been and continues to be an object of discussion (Beillerot, 2006; Ibernom, 2002). For this reason, we have incorporated this aspect particularly into our instruments of observation.

\subsection{COST AND EFFECT AFTER A DECADE OF DIVERSIFICATION OF FUNCTIONS AT THE} IFD: THE INTERPLAY OF THE MACRO SOCIAL AND MESO INSTITUTIONAL LEVELS

Within this framework and faced with gray areas, the creation of INFD and its lines of action (strategies for accompaniment, development of research, generation and/or consolidation of 
documentation centers, etc.), we expected an occasion favorable for consolidating the teacher education system, for reinforcing unity and quality and for attempting to affirm teacher identity. However, the results of empirical research show that we are still far from reaching that objective.

The goal is to improve institutional quality (meso level) and, consequently, the quality of its primary actors, educators of educators (micro level), educators who are key to any improvement. The UNESCO Report reads "continuing education for teachers leads to a better prepared teaching body, able to create better processes of learning and educational experiences for their students. This is a hypothesis sustained by the critical, humanistic and reconstructionist approaches ( $c f$. Lineamientos Nacionales para la Formación Docente Continua y el Desarrollo Profesional, item 8). Again the macro-micro relationship feeds the macro and meso levels. We find ourselves faced with inter-retroaction within a complex system.

\subsection{STATUS OF EDUCATORS OF EDUCATORS: A SEMI-PROFESSION? WHAT IDENTITY?}

We've maintained that the education of educators reveals, firstly, a double issue of identity in the Argentine case: a weakened identity for reasons of institutionalization and a weakened identity of "métier", a weakness which international literature has been making reference to since the 1970s. This situation is even more evident at present for recently graduated teachers who work in disadvantaged contexts and receive new types of students, teachers who have seen an increase in duties due to difficult conditions that neither the Institutes nor the Universities have prepared them for (Barrère, 2002).

Weakened identity (micro level) emerges, then, linked to a macro-social issue, as well as to professionalization and the distance between education received and new demands (meso-macro level).

Let us pause now to look at two aspects: the issue of teacher professionalization and its consequences for professional identity.

\subsection{ON PROFESSIONALIZATION}

Developed particularly in France in the 1980s, the question of professionalization has been widely debated as a result of the implementation of the IUFM (Lang, 1999). The effects of widespread growth, as Gelin, Rayou \& Ria (2007) and Bourdoncle \& Demailly (1998), have pointed out, have given credit to the need to go deeper into the competencies and knowledge essential for the practice of a "métier" and its corollary, the social recognition of the expertise of professional teachers (Bourdoncle, 1993). The model of "reflective practice" (Schön, 1983), capable of reflecting on action, has served as a framework for redefining teaching activity.

However, evaluations of the effects of this model demonstrate teachers' resistance to reforms made to help them face changes. There are different interpretations as to why. On the one hand, we can 
emphasize a lack of reinforcement of professionalism among teachers for formative and professional development, but we also insist on recognizing the difficulties in the field, which leads us to conclude there is a de-professionalization of teachers, confining them to proletarization (Ozga \& Lawn, 1981). Other issues emerge as well, such as the "semi-profession" status assigned to teaching (Etzioni, 1969; Desrosières, Goy, \& Thévenot, 1983), power plays inside workplace organizations (Tardiff \& Lessard, 1999), the devaluation of society's image of teachers (Aparicio, 2006a and b; 2007a and b; 2009a and b, 2005/2009; 2007 a and b HDR; 2012), the inefficacy of education policies (Maroy, 2006), and entry into the "métier" through learning on the job, through practice and the norms of the school context. In this context, insertion may have positive results, but also may be negative as it concerns the acquisition of a desired level of teaching expertise (Schwille \& Dembélé, 2007). In general, we can say that there is tension between theory and practice and, on the other hand, that the "over-prescription" of institutional methods for responding to changes in the school population and its needs is not the same as the "over-prescription" of concrete methods (in terms of education) for responding to these issues.

In Argentina, though research and statistics on this topic are scarce, the situation is no less troubling. According to the results of our latest research (2002-2010), there is great distance between the "ideal" teacher and the "real" teacher working under "contextualized" conditions; between the social representations of teachers (secondary and/or university level) and the world experienced by teachers upon entering the profession; between the image and expectations of the "métier" of a teacher during his or her education and the reality of practice during the first few years (Boutinet, 2005); and between the competencies required by the context and those achieved.

All of this together reveals an identity crisis at the heart of changes in the working world, a crisis that emerges clearly from the social representations that teachers have of their "métier" (Aparicio, 2009b and c). In other words, both identity and pathways - placed between the macro/meso context (professional or otherwise) and the individual - emerge as the fruit of the conjunction of historical and singular aspects, but also of pedagogical-institutional and structural aspects, either favorable or non-favorable. In addition, these more or less blocked identities are also the fruit of negotiations between the yes and the expected recognition in certain spaces by the "other". And today, based on research results, that recognition is dissolving. We are witnessing, then, a crisis of professional identity within a crisis of social identity, instability as rapid changes are not produced without consequences for professional careers. Rupture is common. 


\subsection{TWO MEANINGS OF SOCIALIZATION; TWO TYPES OF IDENTITY}

Two meanings of socialization and identity emerge. Opposite the identifications or “official/virtual” identifying forms (Goffman, 1963: 57 and 12) which come from stereotypes attributed by others (identifications by another), we find "subjective identifications"; opposite the "relational" socialization of actors interacting (identities "by another"), we find the "biographical socialization of actors committed to a social pathway" (identities "by oneself") (Dubar, 1991, 2000; 2000b and 2000c; Dubet, F. \& Martucelli, D., 1996 a and 1996 b).

As regards the matter at hand, these two types of socialization and two types of identity become central to capturing the issue of teachers who must reconcile (though many times this is not achieved) the official or prescribed facet with the subjective facet, the stereotypical image with daily reality.

The identity of a teacher is, then, the fruit of history and of an era marked by specific characteristics. The cultural identity of our community of teachers is not given a priori. Practicing one's "métier" emerges, within this framework, as a privileged means of professional socialization. Understanding the social representations and the factors inherent to "inherited" or "by oneself" identities is, therefore, of interest as the former tend to be accompanied by identity crises which affect both the teacher (especially the novice) and the educational institution in which they work. The dominant conditions at present are that of generalized upset, above all upon entry to the "métier".. Again the interplay between the macro-social, meso-institutional and micro (actor) levels is clear (Aparicio, 2005 2020).

Finally, it is worth asking why the identity aspect of teaching (particularly for teachers recently incorporated into the system) concerns us. We consider that along with the institutional issue - pierced by the issue of fragmentation and a general state of uncertainty - in Argentina we must add the presence of a context favorable to identity crises. Uncertainty dominates. To the issue of institutionalization, still weak, we must add the social issue, subject to rapid and deep changes for which teachers have not been prepared. The issue of competencies emerges at the core. All of this means that, taking into account changes in the conditions of teacher "métier" and its objectives, the education of educators becomes an issue of interest, both at the education level and at the research level, through an interactive/recursive model, with the final goal being improvements to the system.

\section{PART II. EMPIRICAL AND METHODOLOGICAL ASPECTS}

The methodology was quanti-qualitative. 


\subsection{POPULATION SAMPLE}

The sample was made up of teachers from different levels (tertiary or IFD and university), dependencies (public and private), provinces in Argentina (Mendoza and San Juan) and countries (France, Spain and Paraguay).

Each response provided individual and "situated" results, as I have chosen to call them, and it is therefore impossible to generalize as the responses were voluntary and given with informed consent. In this way, it was impossible to achieve a representative sample. Other analyses will be the object of future articles. In this case, we will focus on the findings at the INFOD in Argentina (Mendoza - Cuyo) and the IUFM in East Paris (Créteuil).

Here we will analyze information given by Argentine teachers in terms of recognition as it relates to that given by their colleagues at the IUFM in France ${ }^{3}$.

\subsection{TECHNIQUES}

The study included base, sociocultural, psychosocial, organizational and structural factors.

Techniques included lexicometric analysis, interviews and a semi-structured survey which included open-ended responses in order to allow participants to speak freely on the one hand, and to allow for the utilization of the hierarchical evocation technique on the other. This technique specifically allows for an understanding of shared representations of groups, in this case, of teachers in different contexts.

Many are the items included which allowed us to observe differences between what was found and what was expected, between education received and that which new contexts require; also the "situated" strengths and weaknesses. In order to be brief, we will focus only on items concerning the "Recognition" that teachers receive today, an aspect which is intimately linked to Identity. Identity, like Recognition, is woven between the individual and his or her context, between the history/biography/pathway and what the context recognizes in it, affecting employability, position and promotion in the workplace.

We distinguish between the two groups using their acronyms: Argentina (IFD-ARG) and France (IUFM-FRAN).

Before delving into the techniques, here we list the guiding questions for both the (IFD-ARG) and (IUFM-FRAN) groups.

-Are there differences in representations of recognition between IFD teachers in Argentina and IUFM teachers in France?

\footnotetext{
${ }^{3}$ In another article, we will go into other aspects of the Argentine-French comparative study, in which Prof. Catherine DelanueBretton participated.
} 
-Do these teachers feel prepared to take on the new demands of the context and the devaluation they experience in their daily practice of their métier?

This is connected to another central aspect, that of the formation of non-disciplinary competencies needed to cope with the adversities of life, a topic which Aparicio has worked on since 2009 (Aparicio, 2009 a and b; 2011 a and b, $2020 \mathrm{~b}$ and c, in press; $2020 \mathrm{a}, \mathrm{d}$ and e).

Let us stop for a moment now to discuss the hierarchical evocation technique.

This technique was used (Abric, 2001) in order to understand how the devaluation of social recognition affecting teachers appeared in their shared representations (central or peripheral), as well as the predominance of positive or negative aspects.

Four categories resulted from the combination of the frequency with which words were used and the importance given to them: 1) Educational Dimension; 2) Relational/Motivational Dimension; 3) Socio-institutional Dimension and 4) Economic Dimension. According to the aforementioned combinations, these four categories are located in different quadrants: P1 and P4.

Figure 1. Quadrants (Hierarchical evocation technique) $)^{4}$.

\begin{tabular}{|c|c|}
\hline P1 (-+) & P2 (++) \\
\hline P4 (- -) & P3 (+-) \\
\hline
\end{tabular}

\section{PART III. RESULTS}

\subsection{INSTANCE 1: ARGENTINE CASE (IFD-ARG)}

In the P2 quadrant (nucleus of the representation) are the most frequent and most important categories. However, in the Argentine case (IFD-ARG), none of the four categories was found there. That is, none was frequent enough or important enough in teachers' responses. It was empty.

The same happened in the P3 quadrant, where categories of low frequency and high importance are located for the few that highlighted these as factors associated with weakened social recognition.

The four dimensions were located in the P4 quadrant (those which are overall the least important as they are least frequent and least important) and in the P1 quadrant (low frequency and high importance). These are the so-called elements of contrast or innovators that show group differences.

Through the use of this technique, we were able to understand the most notable convergences and divergences.

In P1 we found: 1) Educational Dimension (low frequency, $\mathrm{LF}=14.2 \%$ and high importance, HI: 18\%) and 2) Relational/Motivational Dimension (LF: 7.4\% and HI: 9\%).

\footnotetext{
${ }^{4}$ Note: Frequency of word appearance is located on the $\mathrm{x}$-axis, while Importance given to the word is located on the $\mathrm{y}$-axis.
} 
In P4 (low frequency, LF and low importance, LI), we found the category 3) Economic Dimension (LF: 5.4\% and LI: 5\%) and 4) Socio-Institutional Dimension (LF: 0\% and LI: 0\%).

\subsection{INSTANCE 2: FRENCH CASE (IUFM-FRAN)}

The results were practically the same as in the Argentine case as regards the location of the four categories.

In the P2 quadrant (nucleus of the representation) - the most significant, and where the most frequent and most important shared representations are located, was empty; none of the four categories was located here; that is, it was not frequent enough or important enough as demonstrated by teachers; it remained empty.

The same occurred in the P3 quadrant, where categories with low frequency but high importance are found for the few that highlight them as factors associated with weakened social recognition. As with the Argentine case, it remained empty.

The four dimensions were located in the P4 quadrant (those which are overall the least important as they are less frequent and less important) and in the P1 quadrant (low frequency and high importance).

In P1 we find only the 1) Educational Dimension (low frequency, LF $=11.5 \%$ and high importance, HI: 15\%)

In P4 (low frequency, LF and low importance, LI), we find the categories 3) Economic Dimension (LF: $5.8 \%$ and 4\%); 4) Socio-institutional Dimension (LF: $0 \%$ and LI: 0\%) and 2) Relational/Motivational Dimension (LF: 0\% and LI: 0\%).

That is, in the French case, all representations associated with Weakened Social Recognition were located almost completely in category one (Educational Dimension) followed by the Economic Dimension.

The other two dimensions had zero responses.

This demonstrates the importance that the French context attributes to the education crisis and insufficient professionalization, which has an impact on the devaluation of teachers.

In the Argentine case, the overall situation is the same, though more importance was given to the Relational/Motivational Dimension.

Findings can be visualized in the following tables and figures. 
Instance 1. Argentine Case (IFD-ARG)

“Weakened Social Recognition” Dimension (IFD-ARG)

Table 1: Social representations of Argentine educators (IFD) according to categories and quadrants.

\begin{tabular}{|l|l|c|c|}
\hline \multicolumn{2}{|c|}{ Subjects } & \multicolumn{2}{c|}{19} \\
\hline \multicolumn{2}{|c|}{ Sub-categories } & \multicolumn{2}{c|}{4} \\
\hline \multirow{2}{*}{ Frequency } & Maximum & 96 & $100 \%$ \\
\cline { 2 - 4 } & High & 24.00 & $25 \%$ \\
\hline \multirow{2}{*}{ Importance } & Maximum & 288 & $100 \%$ \\
\cline { 2 - 4 } & High & 56 & $19 \%$ \\
\hline
\end{tabular}

\begin{tabular}{|c|c|c|c|c|}
\hline Importance & $\mid<<$ Training $>>$ & $\begin{array}{c}<<\text { Political- } \\
\text { institutional }>>\end{array}$ & $\langle<$ Economic $\rangle>$ & $\begin{array}{r}<<\text { Socio- } \\
\text { affective }>>\end{array}$ \\
\hline 1 & $4.2 \%$ & $9.4 \%$ & $1.0 \%$ & $2.1 \%$ \\
\hline 2 & $4.2 \%$ & $7.3 \%$ & $1.0 \%$ & $4.2 \%$ \\
\hline 3 & $4.2 \%$ & $10.4 \%$ & $0.0 \%$ & $2.1 \%$ \\
\hline 4 & $3.1 \%$ & $7.3 \%$ & $3.1 \%$ & $3.1 \%$ \\
\hline 5 & $0.0 \%$ & $0.0 \%$ & $0.0 \%$ & $0.0 \%$ \\
\hline \multirow{3}{*}{ Frequency } & 15 & 33 & 5 & 11 \\
\hline & $15.6 \%$ & $34.4 \%$ & $5.2 \%$ & $11.5 \%$ \\
\hline & Low & High & Low & Low \\
\hline & & & & \\
\hline \multirow{3}{*}{ Importance } & 54 & 117 & 15 & 38 \\
\hline & $19 \%$ & $41 \%$ & $5 \%$ & $13 \%$ \\
\hline & Low & High & Low & Low \\
\hline
\end{tabular}


Figure 1a. Social representations of Argentine educators (IFD) according to quadrants of four levels

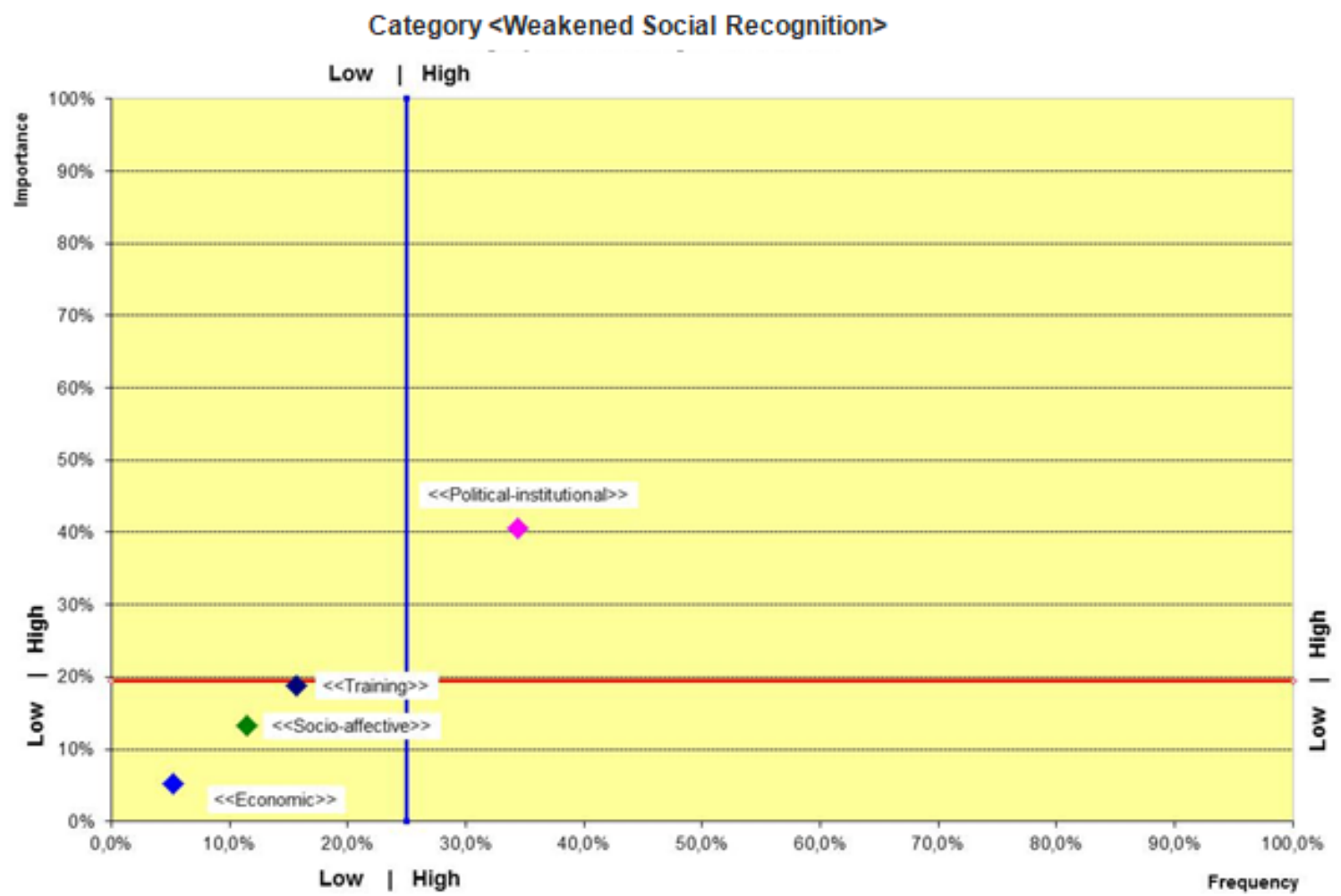

Figure 1b: Social representations of Argentine educators (IFD) according to categories and quadrants. (3D)

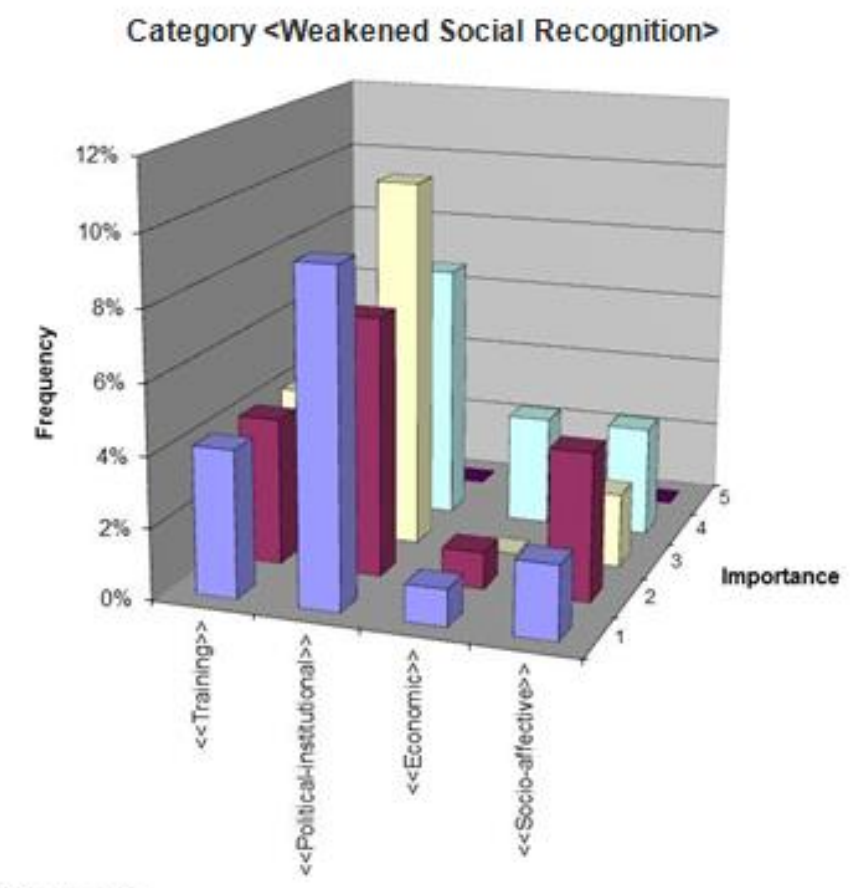

Sub-categories 
Instance 2. French Case (UFM-FRAN)

"Weakened Social Recognition" Dimension (IFD-ARG)

\begin{tabular}{|l|l|c|c|}
\hline \multicolumn{2}{|l|}{ Subjects } & \multicolumn{2}{|c|}{10} \\
\hline \multicolumn{2}{|c|}{ Sub-categories } & \multicolumn{2}{|c|}{4} \\
\hline \multirow{2}{*}{ Frequency } & Maximum & 52 & $100 \%$ \\
\cline { 2 - 4 } & High & 13.00 & $25 \%$ \\
\hline \multirow{2}{*}{ Importance } & Maximum & 156 & $100 \%$ \\
\cline { 2 - 4 } & High & 36 & $23 \%$ \\
\hline
\end{tabular}

\begin{tabular}{|c|c|c|c|c|}
\hline Importance & $<<$ Training $>>$ & $\begin{array}{c}<<\text { Political- } \\
\text { institutional }>>\end{array}$ & $<<$ Economic $>>$ & $\begin{array}{c}<<\text { Socio- } \\
\text { affective }>>\end{array}$ \\
\hline 1 & $7.7 \%$ & $11.5 \%$ & $1.9 \%$ & $0.0 \%$ \\
\hline 2 & $1.9 \%$ & $17.3 \%$ & $1.9 \%$ & $0.0 \%$ \\
\hline 3 & $3.8 \%$ & $13.5 \%$ & $0.0 \%$ & $0.0 \%$ \\
\hline 4 & $1.9 \%$ & $9.6 \%$ & $5.8 \%$ & $0.0 \%$ \\
\hline 5 & $0.0 \%$ & $0.0 \%$ & $0.0 \%$ & $0.0 \%$ \\
\hline \multirow{3}{*}{ Frequency } & 8 & 27 & 5 & 0 \\
\hline & $15.4 \%$ & $51.9 \%$ & $9.6 \%$ & $0.0 \%$ \\
\hline & Low & High & Low & Low \\
\hline \multirow{3}{*}{ Importance } & 32 & 97 & 15 & 0 \\
\hline & $21 \%$ & $62 \%$ & $10 \%$ & $0 \%$ \\
\hline & Low & High & Low & Low \\
\hline
\end{tabular}

Figure 2a. Social representations of French educators (IUFM) according to quadrants of four levels.

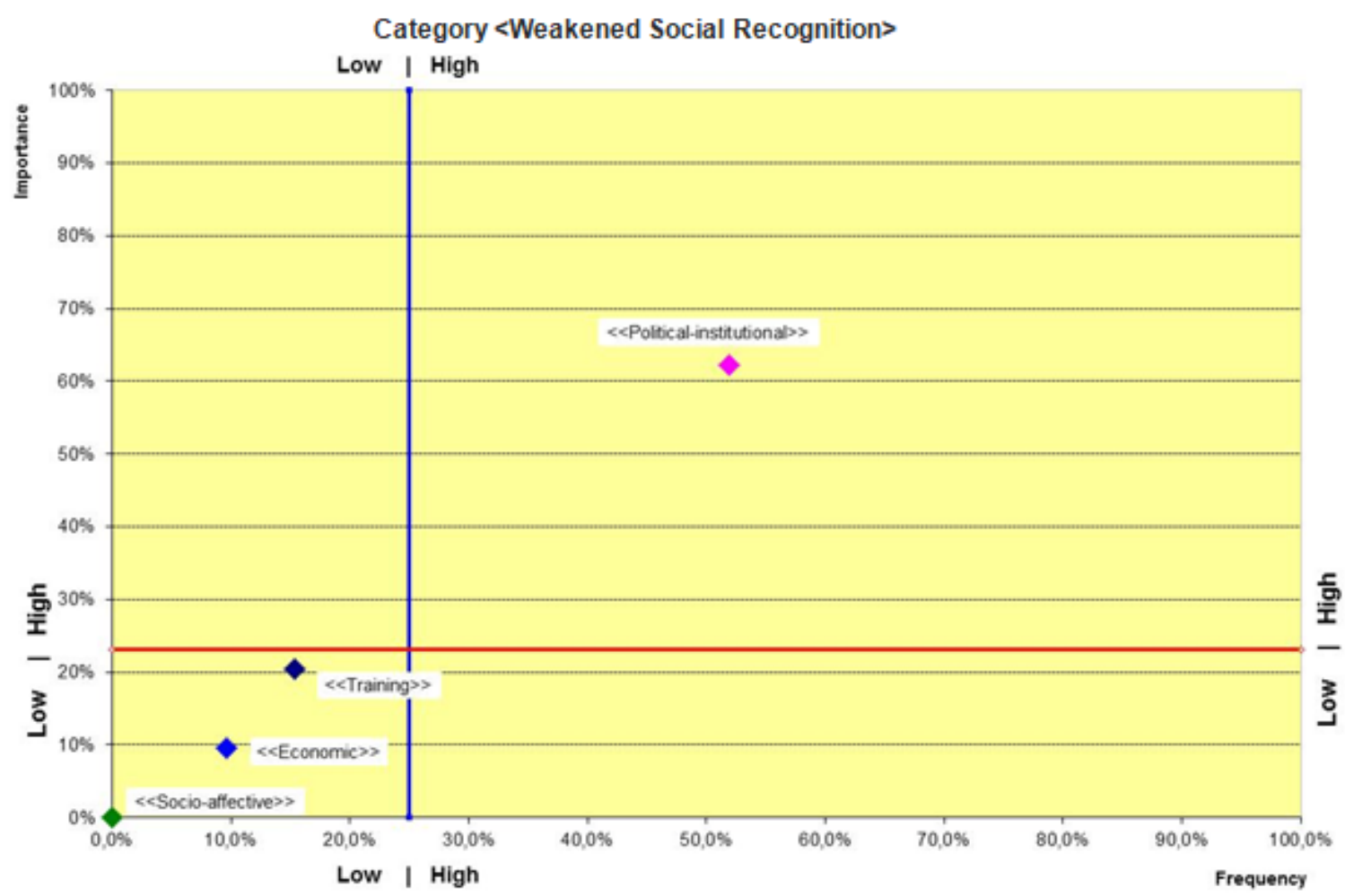


Figure 2b: Social representations of French educators (IUFM) according to categories and quadrants. (3D)

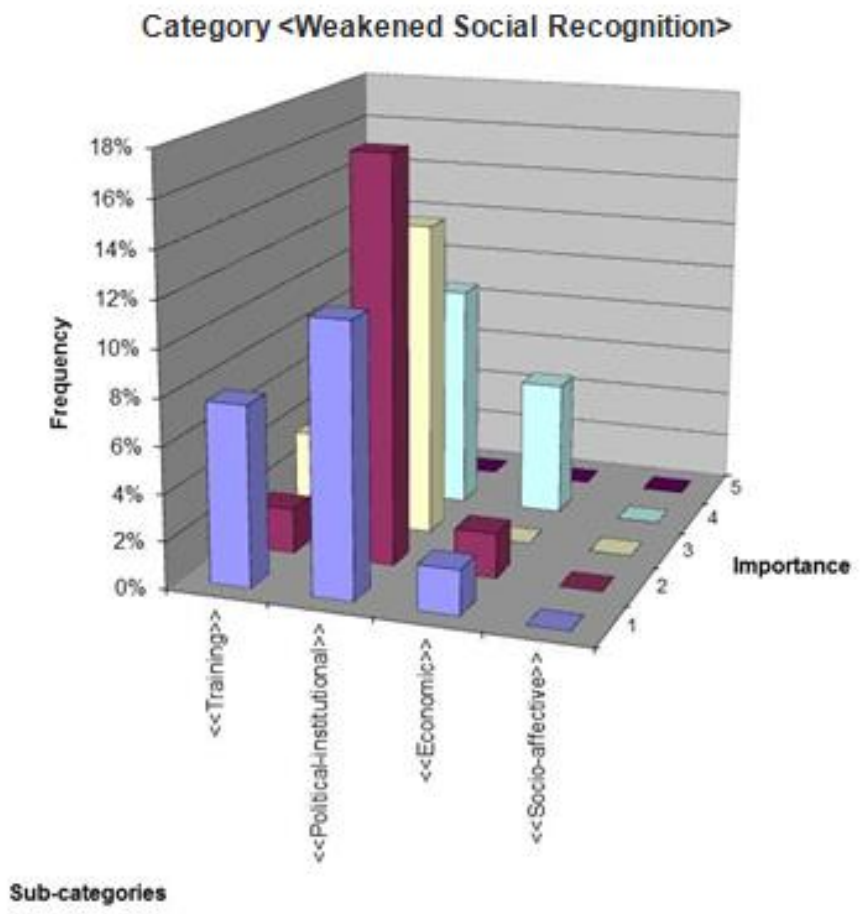

We will now make reference to the terms used by teachers in both the Argentine group and French group.

\section{IFD-ARG}

In the "Educational - Formation Dimension", terms included: "intellectual stagnation", "loss of values", "easiness", "ignorance" (repeated on various occasions), "decontextualization" / "disconnect" (repeated many times), "abstraction", "ingenuity", "idealism", "lack of study" and "lack of training", among others. All of these make reference to a disconnect with or distance from the real world, associated with a lack of renewal and/or professionalization, our focus here.

In the "Motivational - Relational Dimension", we observe that the majority of the responses see daily practice negatively. Respondents describe it as: "submission" and "disrespect / lack of respect" (these words were most used), "stagnation in terms of motivational inertia" / "apathy", "relationships" (alluding to toxic relationships) but also as "service" and "vocation". As is easy to see, this alludes to the fact that more recently attacks against teachers have been observed at schools and in classrooms. The teacher has ceased to be an intellectual and moral authority. For its part, the community does not contribute to improving this "representation" or image of teachers, and as such devaluation increases in an endless spiral. 
On the other hand, in the "Economic" category, the majority of words evoked were negative: "low compensation", "bad salary" (repeated frequently", "budget/salary insufficient to cover needs", "decreasing economic level". The location it occupies is irrelevant, not because the economic aspect has ceased to be important for teachers, but because this is not a new issue, this has been the case since the last century, and teachers know this when electing their profession. If we speak in terms of education models conceived of as either "consumption" or "investment" (Becker, 1961/1983), without a doubt teaching would be the former (Aparicio, HDR, $2007 \mathrm{a}$ and b). Their education does not lead to a better living, and in this sense does not constitute an investment.

Finally, in the "Socio - Institutional" category, the words are: "no professional recognition", "lack of prestige”, “uncertainty”, “dependence”, “legislation”, “scorn”, “undeserving”, “internet”, “social change", "out of control", "society that devalues", "lack of authority", "loss of quality", "government", "strength of unions", "teachers themselves who do not demand professionalization and better working conditions", etc.

This reflects certain nonconformity with the functioning of the workplace in society and at the macro level of governmental policies.

\section{IUFM-FRAN}

As mentioned, the situation in France was very similar to that of the Argentine teachers, with responses concentrated in the "Formation" and "Social - Institutional" dimensions.

In the "Educational - Formation Dimension" - located in quadrant P1 -, terms given were: "change in the profession", "lack of transmission of knowledge" (repeated on many occasions), "disconnect with the economic context", "low level of study" and "not up to current demands", among others.

Like the Argentine group, they allude to decontextualization due to a lack of professionalization and to renewal in accordance with the current needs of the community and workplace.

On the other hand, in the "Economic Dimension" - located in quadrant P4 (that is, the quadrant of low frequency and low importance), - the majority of words evoked were negative: "remuneration", "salary", "money against the teacher".

Curiously, findings from the Argentine group are repeated here. They practically do not cite the economic aspect because it is something understood over time and as such non-conformity is now centered around other aspects. 
In the "Motivational - Relational Dimension"- located in quadrant P4 -, we observe that no teacher even mentioned it. It is not, as in the Argentine case, upset with a growing lack of respect connected to the devaluation of the teaching function.

The same happened with the "Socio-institutional Dimension", which no educator made reference to.

Overall, the concern in France centers upon the education and professionalization that the world today demands if we hope to have an education that functions when dealing with social and workplace requirements of the $21^{\text {st }}$ century.

\section{CONCLUSION}

The findings show that the central issue for both groups is found at the level of education, that of professionalization, which is precisely our focus with this research.

It is not necessary to reiterate that professionalization is related to employability and to insertion into a working world more or less in accordance with expectations set out when selecting the profession. However, the panorama found demonstrates upset, dissatisfaction and generalized non-conformity despite the fact that some still prioritize aspects such as vocation and service above the problems of quality education for the times. The interviews showed, in addition, uncertainty and cracks in identity. As few individuals feel that they have achieved what they expected, many are thinking of changing jobs and restructuring. And this, as is to be expected, will only increase after Covid-19. According to IESALC/UNESCO (2020), many educators were left without work as dropout rates increased and/or because of a lack of digitalization competencies.

Professionalization, described in both groups as being insufficient, presents institutions of education and employment with a challenge if they hope to provide quality instruction in line with the competencies that society now demands.

This is essential, also, because of its impact on the mental and overall wellbeing of teachers, favoring satisfactory entry to the workplace.

Our findings - repeated for other groups and for other inter-intracomparisons carried out in other environments and countries - are, therefore, a call to attention for those who must preserve the human resource and improve institutional quality and personal development. 


\section{REFERENCES}

Abric, J-C. (2001). Prácticas sociales y representaciones. México: Coyoacán.

Aparicio, M. (2005). Les facteurs psychosociaux en relation avec la réussite universitaire et professionnelle. 2e thèse de doctorat. Paris: Université Paris V, Sorbonne. France. Mention: Très honorable avec félicitations du jury.

Aparicio, M. (2006a). Trayectorias universitarias. Un análisis a la luz de metodologías cuantitativas. Proyecto institucional, Universidad Nacional de Cuyo. Versión restringida. Tomo I. Mendoza: ZETA.

Aparicio, M. (2006b). Trayectorias universitarias. Un análisis a la luz de metodologías cualitativas. Proyecto institucional, Universidad Nacional de Cuyo. Versión restringida. Tomo I. Mendoza: ZETA, 294 pp. ISBN: 987-05-2174-6.

Aparicio, M. (2007a). Les facteurs psychosociaux à la base de la réussite universitaire et professionnelle: aspects psychologiques et organisationnels. HDR en Psychologie. Lille: Université de Lille3.

Aparicio, M. (2007b). Mobilité et réussite universitaires et professionnelles. Du niveau macro au niveau micro. HDR en Sciences de l'éducation. Paris: Université Paris X, Nanterre.

Aparicio, M. (2009a). La demora en los estudios universitarios. Causas en el plano cuantitativo. Mendoza: ZETA. Vol.1.

Aparicio, M. (2009b). La demora en los estudios universitarios. Causas en el plano cualitativo. Mendoza: ZETA. Vol.2.

Aparicio, M. (2009c). Les facteurs psychosociaux en relation avec la réussite universitaire et professionnelle. Lille: Presses de 1'Université de Lille3.

Aparicio M. (2011a). Las competencias sociales ¿las grandes ausentes en la formación secundaria y universitaria? Congreso de la Red de Investigación sobre la Calidad de la Educación Superior (RIAICES), Portugal. February 24 -26.

Aparicio, M. (2011b). Les trajectoires des étudiants, un jeu entre les sujets et leurs contextes institutionnels. Book of Abstracts. 8e Congrès de l'UES (Union Européenne de Systémique (UES), On line, Vol. 1.

Aparicio, M. (2012). Trajectoires universitaires/professionnelles et identité. In J. Clénet (Ed.). Formations et professionnalisations: à l'épreuve de la complexité (195-229).Paris: L'Harmattan

Aparicio, M. (2015a). Towards a sui generis Systemic Theory: The Three-Dimensional Spiral of Sense. A Study in Argentina Applied to Identity and Professionalization (Part I). Asian Academic Research Journal an Social Science and Humanities, 2(8) 246-282.

Aparicio, M. (2015b). The Theory of the Three-Dimensional Spiral of Sense: An Application with special Reference to Identity and Professionalization in other Disciplinary Areas (Part 2). Asian Academic Research Journal of Social Sciences \& Humanities, 2(8), 194-245. 
Aparicio, M. et al (2015c). Social Competences and Organisational. 11 Devices in their Relationship with of University Students' Retention. In M. Carmo (Ed.). Education Applications \& Developments 13. Portugal: InScience Press. Portugal. Vol. II. ISSN 2183-2978.

Aparicio, M. (2016). Professionalization and Identity. A Study in Relation to Achievement at University at the Light of a New Paradigm: The Spiral Three Dimensional of Sens. European Journal of Interdisciplinary Studies, 1(3), 126-131.

Aparicio, M. (2016-2019). PICTO. Agence nationale de science, technologie et innovation, Argentine. Projet dirigé par M. Aparicio, intitulé "Trayectorias laborales, Satisfacción, Profesionalización e Identidad. Un estudio en la UNCuyo en distintos contextos organizacionales (científicos, docentes y administrativos)”.

Aparicio, M. (2020a). ICMS XXIII. Resilience: A "Psychosocial" Competency and its Role in the Pathways of University Students in Intercultural Research (Pre and Pos-COVID-19). 23th International Conference on Multidisciplinary Studies: "Resilience for Survival". Cambridge, 20-31 July 2020. Proceedings Book, vol 1, 240-259.

Aparicio, M. (2020 b). Déconfiner les consciences : repenser le monde après la pandémie. Vers un paradigme systémique compréhensif Post COVID-19 pour la «Nouvelle Normalité»: La personne/le citoyen au centre de la culture et le contexte planétaire en interaction, Europeana Systemica, $\mathrm{n}^{\circ} 10$ (in press).

Aparicio, M. (2020 c).Les « compétences absentes ». Une analyse depuis une perspective psychosociale à la lumière de résultats empiriques et d'un nouveau paradigme systémico-compréhensif pour faire face à la 'Nouvelle normalité' Post-Covid-19”, Europeana Systemica (in press).

Aparicio, M. (2020d). Resilience: A "Psychosocial" Competency and Its Role in the Pathways of University Students in Intercultural Research (Pre and Post-Covid 19). European Journal of Interdisciplinary Studies, vol 6, issue 2, 32-51.

Aparicio, M. (2020e). University Pathways of Graduate Students: Professionalization, Innovation and Identity. A French-Argentine Comparative Study. European Journal of Social Sciences Education and Research, 7(1), 99-112.

Barrère, A. (2002). Les enseignants au travail. Routines incertaines. Paris: L’Harmattan.

Beillerot, J. (2006). La formación de formadores. Buenos Aires: Centro de Publicaciones Educativas y Material didáctico.

Becker, G. (1983). El capital humano. Madrid:Alianza.

Boutinet, J.-P. (2005). Anthropologie du projet. Paris: PUF.

Bourdoncle, R. (1993). La professionnalisation des enseignants : les limites d'un mythe. Revue française de pédagogie, 105, 83-119.

Bourdoncle, R \& Demailly, L. (1998) (Comp.). Les professions de l'éducation et de la formation. Paris, Septentrion. 
Demazière, D. \& Dubar, C. (1997). Analyser les entretiens biographiques. L'exemple des récits d'insertion. Paris: Nathan.

Desrosières, A., Goy, A. \& Thévenot, L. (1983). L’identité sociale dans le travail statistique : la nouvelle nomenclature des professions et catégories socioprofessionnelles, Économie et Statistique, 152, 55-81.

Dubar, C. (1991). Formation continue et dynamique des identités professionnelles. Formation et Emploi, 34, 87-100.

Dubar, C. (2000a). La socialisation. Paris: Armand Colin.

Dubar, C. (2000b). La formation professionnelle continue. Paris: La Découverte.

Dubar, C. (2000c). La crise des identités. Paris: PUF.

Dubet, F. \& Martucelli, D. (1996a). Théories de la socialisation et définitions sociologiques de l'école. Revue française de sociol. XXXVII, 511-535.

Dubet, F. \& Martucelli, D. (1996b). En la escuela. Sociología de la experiencia escolar. Buenos Aires: Losada.

Etzioni, A., (1969). The Semi-Professions and Their Organizations. New York: The Free Press.

Gelin, D., Rayou, P. \& Ria, L. (2007). Devenir enseignant. Parcours et Formation. Paris : Armand Colin. Goffman, E. (1963). Stigmates. Les usages sociaux des handicaps. Paris: Minuit.

IESALC/UNESCO. (2020). iESALC insta a los estados a asegurar el derecho a la educación superior en igualdad de oportunidades ante el Covid-19, April 7.

Imbernón, F. (Coord.). (2002). La investigación educativa como herramienta del profesorado. Barcelona: Imprimeix.

Lang, V. (1999). La professionnalisation des enseignants. Paris: PUF.

Maroy, C. (2006). Les évolutions du travail enseignant en France et en Europe: facteurs de changement, incidences et résistances dans l'enseignement secondaire. Revue Française de Pédagogie, 155, 111-142.

Ozga, J. \& Lawn, M. (1981). Teachers Professionalism and Class: A Study of Organised Teachers. London : Falmer Press.

Schön, D. (1982). El profesional reflexivo. Cómo piensan los profesionales cuando actúan. Buenos Aires: Paidós.

Schwille, J. \& Dembélé (2007). Former des enseignants : politiques et pratiques. Principes de la planification de l'éducation, 84. Paris: UNESCO.

Tardif, M. \& Lessard, C., (1999). Le travail enseignant au quotidien. Expérience, interactions humaines et dilemmes professionnels. Bruxelles-Paris : De Boeck Université.

\section{Official Documents}

MECyT, INFD (2007). Lineamientos Curriculares Nacionales para la Formación Docente Inicial. Res. $N^{\circ}$ 
24, CFE, noviembre.

MECyT, INFD (2007). "Hacia un acuerdo sobre la institucionalidad del Sistema de Formación Docente en Argentina", octubre. 